\title{
HYDROXYL AND CALCIUM IONS DIFFUSION FROM ENDODONTIC MATERIALS THROUGH ROOTS OF PRIMARY TEETH - IN VITRO STUDY
}

\author{
AVALIAÇÃO IN VITRO DA DIFUSÃO DE ÍONS Ca ${ }^{+2}$ E OH DE MATERIAIS \\ ENDODÔNTICOS EM DENTES DECÍDUOS
}

Ana Cristina Gerent Petry NUNES ${ }^{1}$, Maria José de Carvalho ROCHA ${ }^{2}$

1- DDS, MSc, PhD Graduate student (Doctor degree), Department of Paediatric Dentistry, Federal University of Santa Catarina.

2- DDS, MSc, PhD, Associate Professor, Department of Paediatric Dentistry, Federal University of Santa Catarina.

Corresponding address: - ANA CRISTINA GERENT PETRY NUNES - Rua Rafael Bandeira, 192, 1002 - Centro, Florianópolis/ SC - Brazil.

Cep.: 88015-450 - Phone: (48) 224-2649 - FAX: (48) 234-8776 - e-mail: crisgp@hotmail.com

Received: August 25, 2004 - Modification: September 28, 2004 - Accepted: December 17, 2004

\begin{abstract}
$T_{\text {h }}$

he purpose of this research was to evaluate the diffusion of calcium $\left(\mathrm{Ca}^{+2}\right)$ and hydroxyl $\left(\mathrm{OH}^{-}\right)$ions from materials with a calcium hydroxide base - $\mathrm{Ca}(\mathrm{OH})_{2}$ through the intact roots of deciduous teeth. This diffusion of ions is important for periapical healing. Forty-six deciduous teeth were selected and instrumented to their working length with \#40 files. The teeth were washed during cleaning and shaping with a $1 \%$ sodium hypochlorite $(\mathrm{NaOCl})$ solution. The canals were dried with paper points. The teeth were divided into 4 groups based on the sealer type, with 10 specimens in each group. A fifth group of 6 teeth without sealer constituted the control group. The materials used as sealers were: $\mathrm{Ca}(\mathrm{OH})_{2}$ paste associated to propylene glycol (CaPE) thickened at the proportion of 2:1 w/v; UFSC (Federal University of Santa Catarina) paste - a mixture of $0.3 \mathrm{~g}$ of zinc oxide with $0.3 \mathrm{~g}$ of $\mathrm{Ca}(\mathrm{OH})_{2}$ with $0.2 \mathrm{ml}$ of olive oil 1:1 w/w; Vitapex ${ }^{\circledR}$ and Sealapex ${ }^{\circledR}$. The coronal access was sealed with a glass ionomer after the root had been filled with each sealer. A one-third apical surface and foramen was hardpressed with Araldite ${ }^{\circledR}$. The teeth were stored individually in flasks containing saline solution at $37^{\circ} \mathrm{C}$ and $100 \%$ humidity. The $\mathrm{OH}^{-}$and $\mathrm{Ca}^{+2}$ ions diffusion levels were determined using a $\mathrm{pH}$ meter and an atomic absorption spectrometer. Data were collected at 48 hours and at intervals of 7, 30, 45 and 60 days. Statistical analysis was performed using ANOVA to compare groups. In the pH evaluation, the CaPE group presented the largest $\mathrm{OH}$ - ions diffusion, which peaked at sixty days ( $\mathrm{p}=0.0309)$, when compared to the other groups $(\mathrm{p}<0.0001)$. In relation to amount of $\mathrm{Ca}^{+2}$ ions released, the CaPE paste showed the best results, followed by the UFSC's paste. These results suggest that the CaPE paste was the material that allowed the highest diffusion of $\mathrm{OH}^{-}$and $\mathrm{Ca}^{+2}$ ions.

Uniterms: Calcium hydroxide; Atomic absorption spectrophotometer; Ion exchange; Root canal filling materials; Primary teeth.
\end{abstract}

\footnotetext{
RESUMO

$O$ objetivo desta pesquisa foi avaliar a difusão de íons $\mathrm{Ca}^{+2} \mathrm{e} \mathrm{OH}-$ de materiais endodônticos a base hidróxido de cálcio - $\mathrm{Ca}(\mathrm{OH})_{2}$, através da raiz intacta de dentes decíduos. 46 dentes decíduos foram selecionados e instrumentados em seu comprimento de trabalho até a lima \# 40, e irrigados durante o preparo com solução de hipoclorito de sódio 1\%, e secos com cones de papel absorvente. Os dentes foram separados em 4 grupos de 10 dentes cada conforme o material obturador, e um grupo controle com 6 dentes permaneceu vazio. Os materiais utilizados como obturadores foram: pasta de $\mathrm{Ca}(\mathrm{OH})_{2}$ associada ao propilenoglicol espessada (CaPE) na proporção de 0,4g de pó para 0,2ml de líquido; pasta UFSC, mistura de 0,3g de pó de óxido de zinco com $0,3 \mathrm{~g}$ de pó de $\mathrm{Ca}(\mathrm{OH})_{2}$ associado a $0,2 \mathrm{ml}$ de óleo de oliva; Vitapex® e Sealapex® Após a obturação, todos os dentes tiveram o forame e terço apical selado com Araldite ${ }^{\circledR}$ e o acesso coronal selado com ionômero de vidro, permanecendo em frascos individuais com a raiz submersa em solução fisiológica, em estufa a $37^{\circ} \mathrm{C}$ em $100 \%$ de umidade. A análise da difusão de íons $\mathrm{OH}^{-} \mathrm{C} \mathrm{Ca}^{+2}$ foi realizada por meio de um pHmetro calibrado e um espectrômetro de absorção atômica, respectivamente, em 48h e em 7, 30, 45 e 60 dias. Conforme o teste estatístico ANOVA para a avaliação do pH, o grupo CaPE apresentou valor estatisticamente significante em relação aos outros grupos ( $\mathrm{p}<0,0001)$, e a maior difusão de íons $\mathrm{OH}^{-}$, ocorreu em 60 dias $(\mathrm{p}<0,0309)$. Em relação a quantidade de íons $\mathrm{Ca}^{+2}$ liberados a pasta CaPE foi a que mostrou melhores resultados, seguida pela pasta UFSC. Conclui-se que a pasta CaPE foi o material obturador que mais difundiu íons $\mathrm{OH}^{-}$e $\mathrm{Ca}^{+2}$.

Unitermos: Hidróxido de cálcio; Espectrofotometria de absorção atômica; Difusão de íons hidroxila; Difusão de íons cálcio; Curativos endodônticos; Dente decíduo.
} 


\section{INTRODUCTION}

Endodontic treatment constitutes a last clinical resort for maintaining deciduous teeth in the oral cavity. It is performed in cases where inflammation, infection, or both, have irreversibly affected the pulp tissue, requiring radical or conservative treatments. In order to achieve success with endodontic treatment it is necessary that all phases be carried out with the aim of maintaining or healing the periradicular tissues, saving the deciduous tooth until eruption of its permanent successor.

As with permanent teeth, the importance of endodontic treatment is the removal of pulp tissue, infected or not, and cleaning of the root canal system ${ }^{21,23,30}$. The biomechanical preparation, comprising instrumentation, irrigation and root canal dressing, represents an important phase of the endodontic treatment, since the instrumentation acts directly on the main root canal while the irrigation and root canal dressing act on the root canal system.

Especially with infected deciduous teeth, endodontic treatment must be undertaken in various sessions ${ }^{2,3}$, with the aim of helping neutralize the residual infection in the root canal systems, as there are no compressive filling techniques for deciduous teeth.

This diffusion of ions is important for periapical healing. The high $\mathrm{pH}$ of calcium hydroxide reduces the number of bacteria and acts on the inflammatory process as a local buffer. Osteoclasts and dentinoclasts have their activity reduced by the action of calcium hydroxide, after which osteogenic mechanisms predominate. $\mathrm{Ca}^{+2}$ ions are necessary for the immunological reaction of the complement system, to reduce local inflammation and initiate the remineralization process ${ }^{10,19,22}$.

Calcium hydroxide as a root canal dressing is widely used for permanent teeth, due to biological properties that make it one of the most effective substances, capable of dissolving tissue, helping with disinfection of the dentinal tubules, acting on bacteria, stimulating the repair process of periapical lesions, helping the osteogenic mechanism and being capable of creating an apical barrier to allow adequate filling of a wide canal ${ }^{6,8,12,13,16,23,27}$.

Considering these points previously mentioned, the purpose of this research was to evaluate the diffusion of $\mathrm{OH}^{-}$and $\mathrm{Ca}^{+2}$ ions from materials based on calcium hydroxide - $\mathrm{Ca}(\mathrm{OH})_{2}$, through the intact roots of deciduous teeth by using $\mathrm{pH}$ meter and atomic absorption spectrometer, respectively.

\section{MATERIALAND METHODS}

\section{Sample selection}

All 46 teeth (23 with single root canals and 23 with multiple root canals) were achieved from the Tooth Bank of the Pediatric Clinic at the Federal University of Santa Catarina (UFSC). The teeth were individually stored in flasks in saline solution. They were macroscopically analyzed with aid of a magnifying glass (20 times), in order to detect areas of resorption or perforation in the root or at the furcation region. To be included in the sample, the anterior and posterior teeth should have at least two thirds of the root; roots without perforation resorption on their apical, middle or cervical thirds; crown conditions to receive and retain a provisional filling; patency of the root canals, that is, to allow passage of the endodontic instrument through the canal to the foramen, without obstacles.

\section{Endodontic preparation of the teeth}

After endodontic access, each tooth was individually shaped to its working length, at $1 \mathrm{~mm}$ short of the tooth's original length, first using series files (\#15 to \#40), moving the instrumentation up to file FF \#35 or \#40 (MAILLEFER $®$ ), depending on the size of the root canal. Between the same size files and between changes of files, irrigation was carried out with $1 \%$ sodium hypochlorite solution $(\mathrm{NaOCl})$ (MIYAKO®).

The sample was separated into 4 groups, each group comprising 10 teeth (5 with single root canals and 5 with multiple root canals), in accordance with the number of experimental groups in which the endodontic materials were tested. A fifth group comprising 6 teeth constituted the control group ( 3 with single root canals and 3 with multiple root canals), in which each tooth was biomechanically prepared but did not receive the filling material.

\section{Composition and preparation of the filling material}

The materials used for fillings were CaPE thickened paste, mixed with $\mathrm{Ca}(\mathrm{OH})_{2}$ and propylene glycol in a proportion of $0.4 \mathrm{~g}$ of powder to $0.2 \mathrm{ml}$ of liquid; UFSC's paste, a mixture of $0.3 \mathrm{~g}$ of zinc oxide powder with $0.3 \mathrm{~g}$ of $\mathrm{Ca}(\mathrm{OH})_{2}$ powder with $0.2 \mathrm{ml}$ of olive oil; Vitapex ${ }^{\circledR}$, used as a root canal dressing; and Sealapex ${ }^{\circledR}$, used as a sealer.

\section{Canal fillings}

The insertion of filling material was similar for all teeth. Therefore, the lentulo spiral instrument (MAILLEFER ${ }^{\circledR}$ ) size 30 , was previously cut to $16 \mathrm{~mm}$ and pre-measured within $1 \mathrm{~mm}$ of the working length of each root. Before the lentulo spiral instrument was inserted into the canal, it was manually tested to verify if penetration into the root canal was sufficiently easy to avoid breaking the instrument.

The canal was considered full when the paste or the sealer flowed from the pulp chamber at the root canal opening; when this happened, vertical compression was applied with a cotton pellet. To check whether the canals were completely filled, individual periapical radiographs were taken in buccolingual direction (film Ultra-speed KODAK®).

If the canal showed radiolucent areas on the radiograph, indicating bubbles or gaps in the filling, this process was repeated to the canal with the help of files, applying more vertical pressure with the aid of the cotton pellet to fill the 
areas where the material was missing, after which another radiograph was taken.

After confirming that the root canal was totally filled, the pulp chamber was cleaned and restored with glass ionomer cement Vidrion R (SSWhite ${ }^{\circledR}$ ) on a cotton pellet that sealed the root canal. The teeth from the control group were also restored using the same technique.

\section{Apical impermeability}

Cleaning of the intact root (with cement) was performed with either solution, to remove debris of the filling material and grease from the external surface and better retain apical impermeability. The material used to make the foramen and apical third impermeable was Araldite ${ }^{\circledR}$ (BRASCOLA Ltda.) mixed in equal parts of base paste and catalyst according to the manufacturer's instructions. After a hardening time of 30 minutes, a layer of nail varnish was applied over the Araldite to make the tooth more impermeable, so that the diffusion of ions only occurred through the roots of teeth.

\section{Teeth storage}

The teeth were stored in individual plastic flasks (as those used to store photographic films for slides), each containing $36 \mathrm{ml}$ of saline solution, which were kept at a constant temperature of $37^{\circ} \mathrm{C}$ and at $100 \%$ relative air humidity during the entire test period. The flasks had a utility wax lid where the tooth's crowns were fixed, allowing only the root to be in contact with the saline solution.

\section{pH analysis}

Measurements were taken at regular intervals for each group, at 48 hours, 7, 30, 45 and 60 days. The $\mathrm{pH}$ was measured using a calibrated electrode (MICRONAL S.A. Model B-374), which was calibrated with standard solutions with $\mathrm{pH} 7.0$ and 9.0 at each date of analysis. The $\mathrm{pH}$ readings were taken for the test and control groups after 2 minutes of electrode immersion in each flask, in the solutions that contained each specimen. After measurement, each tooth was returned to the same flask. Between readings, the electrode was washed with deionized water and dried with absorbent paper. The values obtained were recorded in their respective tables.

\section{Analysis of atomic absorption spectrophotometer}

To determine the concentration of calcium ions, an atomic absorption spectrophotometer (Z-8230 Z-8230 HITACHI's Polarized Zeeman) was used. The operational parameters were the following: wavelength $422.7 \mathrm{~nm}$; flame air/acetylene; slit width $1.3 \mathrm{~nm}$; lamp current $7.5 \mathrm{~mA}$; height of the burner 7.5mm; and acetylene flow 1.91/ $\mathrm{min}$.

To analyze the calcium ions release, $0.5 \mathrm{ml}$ was removed with a pipette from each flask $(n=10)$ of the test groups and put in a sterile test tube pertaining to the group. Therefore, $5 \mathrm{ml}$ were put in a test tube to analyze the diffusion of $\mathrm{Ca}^{+2}$ ions from each test group.

A small quantity from these $5 \mathrm{ml}$ of solution from the test tube of each test group (never less than $0.1 \mathrm{ml}$ ) was removed with a pipette for analysis, which was diluted according to the saturation of the solution. It was necessary to dilute the samples from the same saline solution to obtain the values for each group and not exceed the equipment's range of calibration, which in this case allowed up to $2 \mu \mathrm{g} / \mathrm{ml}$ (ppm). At the time of readings, the solutions were at room temperature. Readings were taken from the tube samples and individually from each control group flask at 48-hour, 7, 30-, 45- and 60-day intervals.

\section{RESULTS}

The statistical analysis was based on data obtained from long-term $\mathrm{pH}$ readings for each group and during the evaluated time period. Analysis of Variance (ANOVA) was applied. Data obtained by atomic absorption spectrometry were submitted to descriptive analysis.

Table 1 reveals that the mean $\mathrm{pH}$ for all study periods was similar for all materials tested and for the control group. However, a higher standard deviation occurred for the CaPE group, which means that this material made the area more alkaline than the others.

The CaPE paste, which is a thickened calcium hydroxide mixture - that is, with more quantity of powder than liquid mixed with an aqueous agent, presented a constant $\mathrm{OH}^{-}$ ions release during the study periods up to 45 days. There was a slight increase in this on the $60^{\text {th }}$ day (Table 1 ). In relation to the other materials tested, the CaPE paste showed

TABLE 1- mean $\mathrm{pH}$ for all periods and groups

\begin{tabular}{|c|c|c|c|c|c|c|c|c|c|c|}
\hline \multirow{2}{*}{$\begin{array}{l}\text { Time } \\
\text { Groups }\end{array}$} & \multicolumn{2}{|c|}{48 hours } & \multicolumn{2}{|c|}{5 days } & \multicolumn{2}{|c|}{30 days } & \multicolumn{2}{|c|}{45 days } & \multicolumn{2}{|c|}{60 days } \\
\hline & $\mathbf{M}$ & (SD) & M & (SD) & M & (SD) & M & (SD) & M & (SD) \\
\hline CaPE & 7.52 & $(0.411)$ & 7.50 & $(0.325)$ & 7.44 & $(0.741)$ & 7.55 & $(0.662)$ & 7.89 & (0.428) \\
\hline UFSC & 7.05 & $(0.472)$ & 7.30 & $(0.231)$ & 7.28 & $(0.463)$ & 6.95 & $(0.419)$ & 7.20 & $(0.233)$ \\
\hline VITAPEX & 7.09 & $(0.264)$ & 7.31 & $(0.176)$ & 7.45 & $(0.469)$ & 7.33 & $(0.498)$ & 7.51 & (0.398) \\
\hline SEALAPEX & 7.24 & $(0.541)$ & 7.35 & $(0.192)$ & 7.19 & $(0.361)$ & 7.38 & $(0.419)$ & 7.39 & $(0.321)$ \\
\hline Control & 7.03 & (0.158) & 7.15 & (0.159) & 7.02 & $(0.231)$ & 7.38 & (0.188) & 7.34 & $(0.391)$ \\
\hline
\end{tabular}

Legend: M: mean; SD: standard deviation. 
higher levels of $\mathrm{OH}^{-}$ion diffusion at 48 hours and 60 days (Table 1). These results analyzed by the ANOVA test showed a statistically significant difference between materials $-\mathrm{p}<$ 0.0001 .

The UFSC's paste and Vitapex showed similar results as the control group in the first 48 hours, with a slight increase in $\mathrm{OH}^{-}$ion diffusion with time, probably due to characteristics of the agents used - oil and silicone, respectively (Table 1).

It is important to emphasize that, when compared to the control group, all materials showed that the absolute dispersion value of $\mathrm{OH}^{-}$ions was considered low - that is, close to neutral (Table 1). This can be explained by the presence of root cement, which impairs the diffusion of ions ${ }^{8}$ 17,24

The control group released $\mathrm{Ca}^{+2}$ ions, despite the teeth were empty, because the tooth itself can release $\mathrm{Ca}^{+2}$ ions from its structure (Figure 1).

Each test group comprised equal numbers of singlerooted and multi-rooted teeth, and it was verified that multirooted teeth released a higher quantity of ions than singlerooted teeth. The control group (Figure 1) also confirms a higher $\mathrm{Ca}^{+2}$ ion release from multi-rooted teeth (teeth $1 \mathrm{~m}$, $2 m, 3 m)$.

The results showed that the diffusion of $\mathrm{Ca}^{+2}$ ions (Figure 2) occurred in all groups, in agreement with the materials evaluated. CaPE paste was the filling material that most released $\mathrm{Ca}^{+2}$ ions and achieved the highest mean in 60 days, with a statistically significant difference between groups; nevertheless, the release of $\mathrm{Ca}^{+2}$ ions was more accentuated in the first 30 days for all test groups (Figure 2).

\section{DISCUSSION}

The endodontic treatment performed on infected teeth presents a higher failure rate, resulting from residual infection even after careful biomechanical preparation, especially in those cases where periapical lesions are present ${ }^{14,27}$. This situation is the same for deciduous teeth, in which failure cases may also be related to infected teeth ${ }^{2,15}$. As a result, it is necessary to use root canal dressings, which are able to heal a chronic lesion and facilitate bone tissue repair ${ }^{11,12,14,28}$.

For this release to occur "only" through the root walls, those specimens presenting resorption of the middle root third visible with a magnifier (20x magnification) were excluded during macroscopic selection. Also, apical resorption areas and the foramen were sealed to avoid leakage of ions through these areas ${ }^{8,9,24}$. The teeth were kept with the root submerged only in saline solution, to avoid that the coronary part interfered with the release of $\mathrm{Ca}^{+2}$ ions. The $\mathrm{pH}$ value of the teeth with intact cement was not influenced by the root canal calcium hydroxide filling, and only in external inflammatory resorption areas (with no cement) the $\mathrm{OH}^{-}$ions reached the periodontal ligament, raising the $\mathrm{pH}$ on the area ${ }^{26}$.

However, it can be confirmed that $\mathrm{OH}^{-}$ion diffusion in deciduous teeth, in vivo, will happen more intensely than shown in this research, due to the presence of physiological resorptions near the dental follicle of the permanent tooth bud and in other root areas due to the presence of apoptosis or to the apical foramen itself.

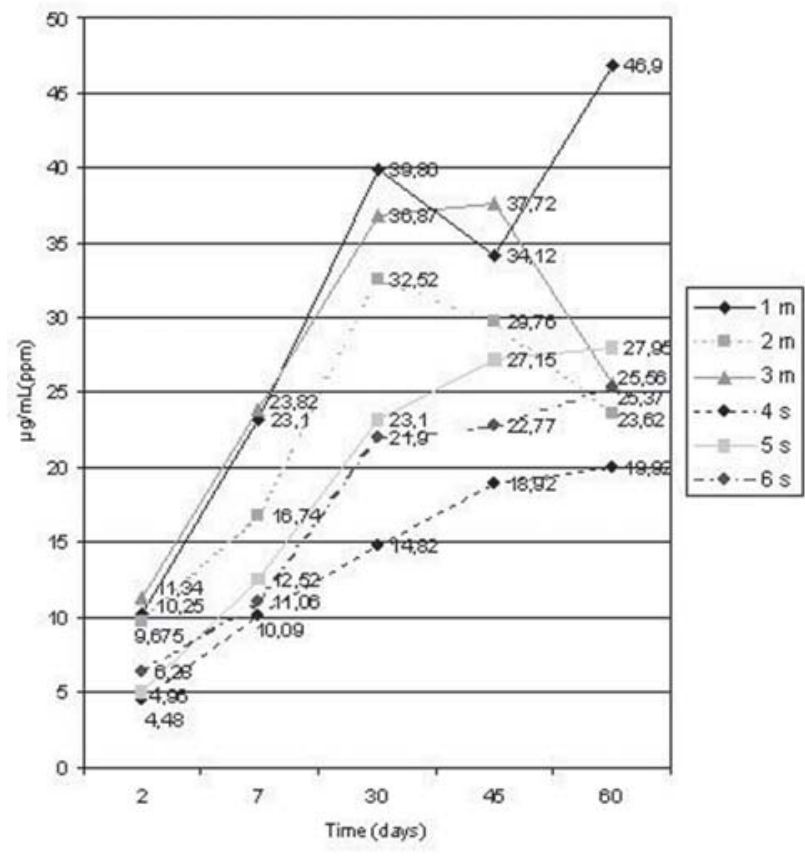

Legend - $\mathrm{m}$ : multirooted; s: single root.

FIGURE 1- Calcium ion diffusion through test time (days) measure in $\mu \mathrm{g} / \mathrm{mL}$ (ppm) for control group

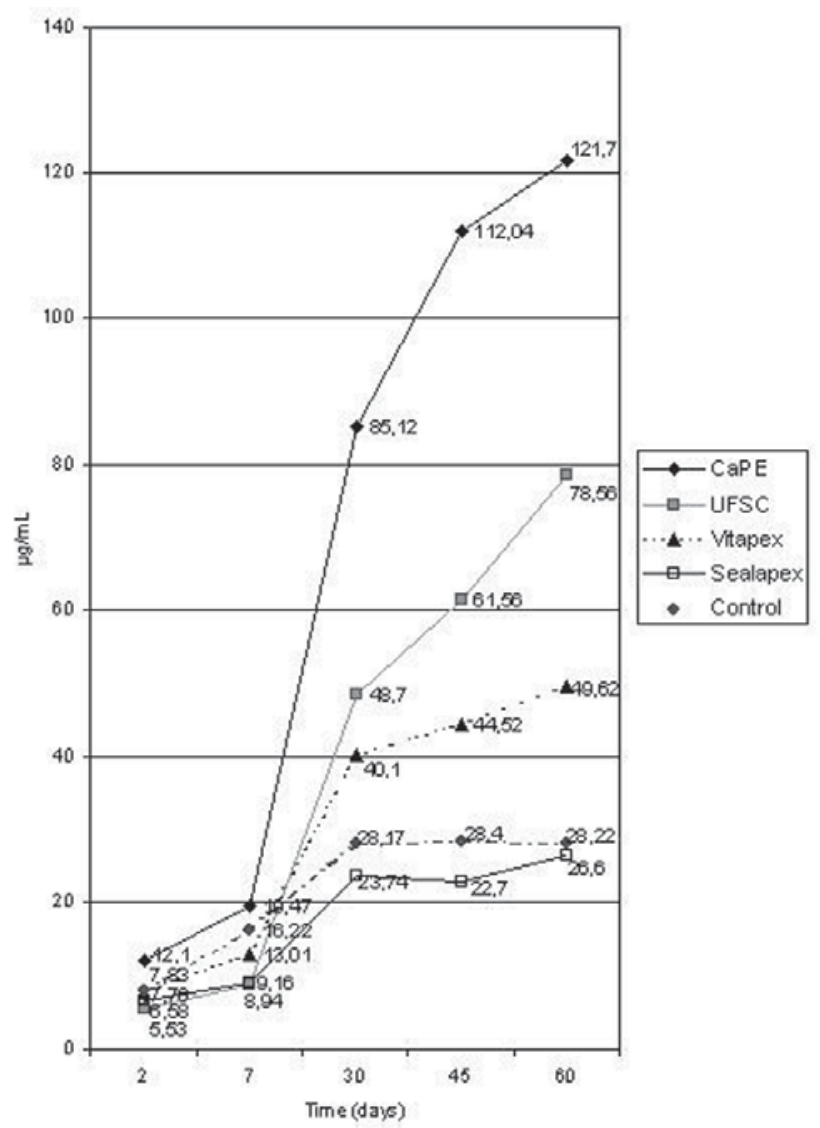

FIGURE 2- Calcium ion diffusion through test time (days) measure in $\mu \mathrm{g} / \mathrm{mL}$ (ppm) for all groups 
Although the methodology of studies reviewed in the literature adopted utilization of only single-rooted teeth ${ }^{5,17,19}$, in this research the distribution of specimens in the test groups comprised equal numbers of single-rooted and multirooted teeth. Based on the pilot analysis of $\mathrm{Ca}^{+2}$ ions release from multi-rooted teeth, it was verified that these teeth released a higher quantity of ions than single-rooted teeth. Thus, as the objective was to analyze $\mathrm{Ca}^{+2}$ ion dispersion from the experimental groups as a whole, these teeth should present the same profile for examination.

The biomechanical preparation consists of root canal instrumentation, irrigation and placement of the root canal dressing. The instrumentation of deciduous teeth followed the same criteria adopted by Resende ${ }^{20}$.

Irrigation during and after biomechanical preparation of teeth was performed with $1 \% \mathrm{NaOCl}$ solution, as this is the irrigant used for endodontic treatment in deciduous teeth in the UFSC's protocol. The $1 \% \mathrm{NaOCl}$ solution has low superficial tension, antimicrobial action, promotes pulp tissue dissolution, and this capacity is increased when used with root canal dressings containing calcium hydroxide ${ }^{29}$. However, the $\mathrm{Ca}^{+2}$ ions are better diffused through the dentinal mass in which EDTA ${ }^{28}$ irrigations are undertaken. Besides, this facilitates the penetration of sealers. However, in pediatric dentistry, the use of "more than one" substance for irrigation would be relevant if its use allowed a different way of diffusion of $\mathrm{OH}^{-}$and $\mathrm{Ca}^{+2}$ ions. The results showed that the diffusion of these ions happened in all groups irrigated with $1 \%$ NaOCI (Table 1 and Figure 2).

Selection of the materials tested in this research (CaPE paste, UFSC and Vitapex) was justified by their use as root canal dressings in the UFSC's protocol for endodontic treatment in deciduous teeth. The perspective of future use of Sealapex as a sealer is corroborated by other researches concerning its biological performance $e^{4,7,14}$.

Despite its partial hardening in 1 week $^{1}$, the Sealapex sealer continued to release hydroxyl ions during the entire study period, but did not make the external root surface alkaline ${ }^{5}$; this material released $\mathrm{OH}^{-}$ions, yet to a lower degree when compared to an aqueous solution ${ }^{4,25}$. Besides, the Sealapex sealer can be resorbed by the body, which is an important characteristic for filling of deciduous teeth that will go through a physiological process of root resorption ${ }^{7}$.

The main differences between the materials were the characteristics of the agents employed, which in this case were three pastes with the function of dressing and a filling sealer. It is important to stress that the CaPE and UFSC's pastes are thick, and the agents used have different viscosity and solubility and consequently differ in the speed with which they release ions ${ }^{24}$. Propylene glycol is an alcohol with dispersing properties; oil and silicone have aggregating properties. Silicone is present in the Vitapex formula, a filling material appropriate for deciduous teeth ${ }^{18}$. The clinical recommendation for the use of these pastes is directly related to the agent used. When the paste needs to remain in the canal for a longer period, the indication is for an aggregating agent (oily); however, when there is need of a larger dispersion of calcium hydroxide, an aqueous agent is used (propylene glycol).

As shown by the data in Figure 2, among the materials evaluated, the group that released more $\mathrm{Ca}^{+2}$ ions was the CaPE group, followed by the UFSC's paste, Vitapex and Sealapex. It was also observed that the $\mathrm{Ca}^{+2}$ ion release was greater in the first 30 days, nearly 5 times higher than in the first seven days for the UFSC group, and this tendency was also shown by the CaPE group, for which the rate was approximately 4.5 times higher. Some authors have already reported that, in permanent teeth, the $\mathrm{Ca}^{+2}$ ions reach the external area even with the presence of root cement ${ }^{8,17,24}$.

The $\mathrm{Ca}^{+2}$ ions diffusion from the Sealapex sealer was not related to the material, as the values found for $\mathrm{Ca}^{+2}$ ion diffusion remained below the values of the control group during the entire study period, indicating that the origin of these ions was the dental element itself, and even the sealer hardening could remove $\mathrm{Ca}^{+2}$ ions from the teeth.

The relevance of this research is based on results that indicate the importance of each material for each clinical situation. Thus, when treating an infected tooth with a periradicular lesion, the ideal would be to use a root canal dressing containing all properties present in calcium hydroxide, with fast ion dispersion, in the form of a thickened paste (CaPE), or associated with iodoform (Vitapex), which contains additional antiseptic properties.

For deciduous teeth of very young children, the ideal is to use a root canal dressing with slower dispersion and dissolving properties, such as the UFSC's paste. That is important to maintain the dressing for a longer period. The tooth should not be obturated in 1 week; instead, it is best to wait at least 1 month to allow a residual action of the $\mathrm{Ca}(\mathrm{OH})_{2}$ dressing, thus allowing better wound healing.

Therefore, after apical repair, the endodontic sealer represents the last phase of obliteration of the space previously filled by the pulp tissue, draining off to the ramifications and improving the adaptation of fillings to the root canal's irregularities. In addition to that, the sealer should have property of maintaining an alkaline environment for a long period as the exfoliation of deciduous teeth occurs, reducing the possibility of bacterial re-infection. These findings confirm that the Sealapex can be recommended for filling of deciduous teeth.

\section{CONCLUSIONS}

1- The CaPE paste was the filling material that most diffused $\mathrm{OH}^{-}$ions and achieved the highest mean at 60 days. There was a statistically significant difference between groups.

2- The CaPE paste was the filling material that most diffused $\mathrm{Ca}^{+2}$ ions, followed by the UFSC's paste, Vitapex, control and Sealapex. The greatest diffusion of ions took place between 7 and 30 days. That is important to maintain the dressing for more time. The tooth should not be obturated after a week, but at least 1 month should be allowed to permit the residual action of the $\mathrm{Ca}(\mathrm{OH})_{2}$ dressing and allow better wound healing. 


\section{REFERENCES}

1- Allan NA, Walton RC, Schaeffer MA, Schaffer A. Setting times for endodontic sealers under clinical usage and in vitro conditions. J Endod. 2001;27(6):421-3.

2- Bortolini L. Avaliação longitudinal dos sucessos e insucessos dos tratamentos endodônticos de dentes decíduos realizados pela técnica UFSC. Florianópolis: Universidade Federal de Santa Catarina; 2002.

3- Coll JA, Sadrian R. Predicting pulpectomy success and its relationship to exfoliation and succedaneous dentition. Pediatr Dent. 1996;18(1):57-63.

4- Duarte MA, Demarchi AC, Giaxa MH, Kuga MC, Fraga SC, de Souza LC. Evaluation of $\mathrm{pH}$ and calcium ion release of three root canal sealers. J Endod. 2000;26(7):389-90.

5- Esberard RM, Carnes DL, Jr., Del Rio CE. pH changes at the surface of root dentin when using root canal sealers containing calcium hydroxide. J Endod. 1996;22(8):399-401.

6- Estrela C, Sydney GB, Bammann LL, Felippe Junior O. Mechanism of action of calcium and hydroxyl ions of calcium hydroxide on tissue and bacteria. Braz Dent J. 1995;6(2):85-90.

7- Garcia LD. Avaliação radiográfica digital e microscópica óptica da reabsorção dos cimentos Sealapex, Sealapex com iodofórmio e óxido de zinco e eugenol. Implantes em tecidos subcutâneos de ratos. [Dissertação]. Araçatuba, SP: Universidade estadual Paulista; 2003.

8- Gomes IC, Chevitarese O, de Almeida NS, Salles MR, Gomes GC. Diffusion of calcium through dentin. J Endod. 1996;22(11):590-5.

9- Guigand M, Vulcain JM, Dautel-Morazin A, Bonnaure-Mallet M. In vitro study of intradentinal calcium diffusion induced by two endodontic biomaterials. J Endod. 1997;23(6):387-90.

10- Heithersay GS. Calcium hydroxide in the treatment of pulpless teeth with associated pathology. J Br Endod Soc. 1975;8(2):74-93.

11- Holland R, Otoboni Filho JA, de Souza V, Nery MJ, Bernabe PF, Dezan E, Jr. A comparison of one versus two appointment endodontic therapy in dogs' teeth with apical periodontitis. J Endod. 2003;29(2):121-4.

12- Katebzadeh N, Sigurdsson A, Trope M. Radiographic evaluation of periapical healing after obturation of infected root canals: an in vivo study. Int Endod J. 2000;33(1):60-6.

13- Leonardo MR, Bezerra da Silva LA, Utrilla LS, Leonardo Rde T, Consolaro A. Effect of intracanal dressings on repair and apical bridging of teeth with incomplete root formation. Endod Dent Traumatol. 1993;9(1):25-30.

14- Leonardo MR, Silva LA, Utrilla LS, Assed S, Ether SS. Calcium hydroxide root canal sealers-histopathologic evaluation of apical and periapical repair after endodontic treatment. J Endod. 1997;23(7):428-32.

15- Mani SA, Chawla HS, Tewari A, Goyal A. Evaluation of calcium hydroxide and zinc oxide eugenol as root canal filling materials in primary teeth. ASDC J Dent Child. 2000;67(2):142-7, 83.

16- Minana M, Carnes DL, Jr., Walker WA, 3rd. PH changes at the surface of root dentin after intracanal dressing with calcium oxide and calcium hydroxide. J Endod. 2001;27(1):43-5.

17- Nerwich A, Figdor D, Messer HH. pH changes in root dentin over a 4-week period following root canal dressing with calcium hydroxide. J Endod. 1993;19(6):302-6.
18- Nurko C, Garcia-Godoy F. Evaluation of a calcium hydroxide/ iodoform paste (Vitapex) in root canal therapy for primary teeth. J Clin Pediatr Dent. 1999;23(4):289-94.

19- Rehman K, Saunders WP, Foye RH, Sharkey SW. Calcium ion diffusion from calcium hydroxide-containing materials in endodontically-treated teeth: an in vitro study. Int Endod J. 1996;29(4):271-9.

20- Resende GB. Análise in vitro das zonas de perigo no preparo biomecânico de canais radiculares de dentes decíduos [Dissertação]. Florianópolis: Universidade Federal de Santa Catarina; 2002.

21- Rocha MJ, Cardoso M. Traumatized permanent teeth in Brazilian children assisted at the Federal University of Santa Catarina, Brazil. Dent Traumatol. 2001;17(6):245-9.

22- Segura JJ, Llamas R, Rubio-Manzanares AJ, Jimenez-Planas A, Guerrero JM, Calvo JR. Calcium hydroxide inhibits substrate adherence capacity of macrophages. J Endod. 1997;23(7):444-7.

23- Sheehy EC, Roberts GJ. Use of calcium hydroxide for apical barrier formation and healing in non-vital immature permanent teeth: a review. Br Dent J. 1997;183(7):241-6.

24- Simon ST, Bhat KS, Francis R. Effect of four vehicles on the $\mathrm{pH}$ of calcium hydroxide and the release of calcium ion. Oral Surg Oral Med Oral Pathol Oral Radiol Endod. 1995;80(4):459-64.

25- Staehle HJ, Spiess V, Heinecke A, Muller HP. Effect of root canal filling materials containing calcium hydroxide on the alkalinity of root dentin. Endod Dent Traumatol. 1995;11(4):163-8.

26- Tronstad L, Andreasen JO, Hasselgren G, Kristerson L, Riis I. pH changes in dental tissues after root canal filling with calcium hydroxide. J Endod. 1980;7(1):17-21.

27- Trope M, Delano EO, Orstavik D. Endodontic treatment of teeth with apical periodontitis: single vs. multivisit treatment. J Endod. 1999;25(5):345-50.

28- Trope M, Moshonov J, Nissan R, Buxt P, Yesilsoy C. Short vs. long-term calcium hydroxide treatment of established inflammatory root resorption in replanted dog teeth. Endod Dent Traumatol. 1995;11(3):124-8.

29- Turkun M, Cengiz T. The effects of sodium hypochlorite and calcium hydroxide on tissue dissolution and root canal cleanliness. Int Endod J. 1997;30(5):335-42.

30- Yang SF, Rivera EM, Walton RE, Baumgardner KR. Canal debridement: effectiveness of sodium hypochlorite and calcium hydroxide as medicaments. J Endod. 1996;22(10):521-5. 